\title{
Komparasi Hasil Belajar Matematika antara Pembelajaran Terbalik dengan Pembelajaran Konvensional pada Siswa Kelas VII di SMP Muhammadiayah Sorong
}

\begin{abstract}
ABSTRAK
Penelitian ini adalah Penelitian Eksperimen (quasi eksperimen) yang dilaksanakan di SMP Al Amin Kota Sorong. Masalah penelitian ini adalah : (1) Seberapa besar hasilbelajar siswa pada pokok bahsan pecahan melalui metode pembelajaran terbalik (Reciprocal Teaching)? (2) Seberapa besar hasil belajar siswa pada pokok bahasan pecahan melalui metode konvensional? (3) Apakah hasil belajar siswa pada pokok bahasan pecahan dengan menggunakan metode pembelajaran terbalik (reciprocal teaching) lebih baik dibandingkan dengan menggunakan metode konvensional?. Populasi penelitian adalah siswa kelas VII SMP Al Amin Kota Sorong. Teknik pengambilan sampel adalah claster random sampilng. Pengambilan data dilakukan dengan menggunakan tes hasil belajar dan observasi. Untuk pengolahan data penelitian digunakan statistik deskriptif dan statistik inferensial. Dari hasil pengolahan diperoleh kesimpulan sebagai berikut: (1) Hasil belajar untuk pokok bahasan bilangan pecahan kelas VII SMP Al Amin Kota Sorong yang diajar dengan model pembelajaran terbalik (Reciprocal Teaching) berada dalam kategori tinggi dengan skor rata-rata 75,79 dari skor ideal 100 dan standar deviasi 5,64; (2) Hasil belajar matematika pokok bahasan bilangan pecahan yang diajar dengan metode konvensional berada dalam kategori rendah dengan skor rata-rata 54,87 dari skor ideal 100 dengan standar deviasi 10,30; (3) Hasil penelitian menunjukkan bahwa hasil belajar matematika pokok bahasan bilangan pecahan pada siswa yang diajar dengan model pembelajaran terbalik (reciprocal teaching) lebih baik dibandingkan dengan hasil belajar matematika siswa yang diajar dengan metode pembelajan konvensional
\end{abstract}

Keyword: Pembelajaran Terbalik, Hasil Belajar, Konvensional

\section{PENDAHULUAN}

Pendidikan pada hakekatnya
adalah suatu usaha sadar yang
dilakukan dalam rangka menciptakan
sumber daya manusia yang berkualitas, sehingga dapat berguna bagi bangsa dan negara, terutama sebagai penerus yang diharapkan mampu meningkatkan taraf pendidikan khususnya. Dalam pendidikan nasional, ada penjenjangan pendidikan jalur sekolah, yaitu pendidikan dasar, pendidikan menengah dan pendidikan tinggi.

Perwujudan manusia yang berkualitas melalui pendidikan utamanya dalam penguasaan ilmu pengetahuan dan teknologi, oleh karena itu matematika sebagai suatu ilmu dasar memegang peranan penting dalam menciptakan sumber daya manusia yang berkualitas. Matematika menjadi salah satu mata pelajaran yang dibutuhkan oleh siswa untuk mendapatkan kemampuan yang lebih baik dalam penguasaan ilmu pengetahuan dan teknologi, seperti yang dikemukan oleh Djaali (Sakarani,2005:1), bahwa: "Matematika merupakan sarana berpikir ilmiah, memegang peranan yang sangat penting dalam pengembangan ilmu pengetahuan dan teknologi untuk meningkatkan kesejahteraan bangsa ".

Mengingat peranan matematika sangat penting, maka guru dituntut melaksanakan usaha-usaha perbaikan 
pengajaran baik dalam hal materi maupun metode pengajaran yang tentunya sesuai dengan kebutuhan siswa, dengan demikian maka prestasi siswa tersebut dapat meningkat. Keberhasilan seorang guru dalam mengajar terletak pada kemampuannya dalam memilih metode pengajaran dan melaksanakan proses belajar mengajar yang sebaik-baiknya dalam arti siswa dapat mencapai tujuan yang telah ditetapkan.

Pelaksanakan pembelajaran di dalam kelas merupakan salah satu tugas utama guru. Pembelajaran diartikan sebagai kegiatan yang dapat ditujukan untuk mempelajari bahan pengajaran. Dominasi guru dalam proses pembelajaran dengan menerapkan metode ceramah menyebabkab siswa dengan sendirinya dapat memahami materi yang diajarkan, keterampilan atau sikap yang mereka butuhkan, kondisi seperti ini tidak akan menumbuhkembangkan aspek kemampuan siswa seperti yang diharapkan. Pada umumnya guru memulai pembelajaran langsung pada pemaparan materi, kemudian pemberian contoh soal dan selanjutnya mengevaluasi siswa melalui latihan soal, sehingga mengakibatkan minat belajar siswa menurun pada pelajaran matematika dikarenakan kualitas pengajaran yang rendah. Berdasarkan hasil wawancara dengan guru bidang studi matematika SMA Muhammadiyah Al Amin Kota Sorongpada tahun ajaran 2015-2016 hasil belajar matematika siswa SMA Muhammadiyah Al Amin Kota Sorong berada dibawah rata-rata bahkan tergolong sangat rendah sebagai standar keberhasilan, sehingga guru merasa prihatin dan ingin memperbaiki keadaan tersebut dengan melaksanakan pembelajaran yang akan membuat siswa dapat belajar aktif.

Rendahnya tingkat penguasaan peserta didik terhadap matematika merupakan indikator bahwa perlu adanya pembelajaran matematika yang baik, yang dapat meningkatkan pengusaan peserta didik terhadap mata pelajaran matematika.

Pembelajaran matematika disekolah seharusnya tidak lagi berorientasi pada materi pelajaran, tetapi berorientasi pada kompetensi siswa yang meliputi pengetahuan, keterampilan dan nilai-nilai dasar yang diharapkan dapat direfleksikan dalam kebiasaan berpikir dan bertindak. Siswa harus diupayakan menjadi subjek belajar yang aktif mengkostruksikan atau membangun sendiri pemahaman terhadap materi yang dipelajari, sedangkan guru sebaiknya berperan sebagai fasilitator dan mediator yang kreatif agar siswa dapat belajar dalam suasana yang menyenangkan. Hal ini sejalan dengan kurikulum yang diarahkan untuk mengembangkan pengetahuan, pemahaman, kemampuan menilai, sikap dan minat peserta didik khususnya dalam berpikir logis dengan daya nalar yang tinggi. Oleh karena itu matematika sebagai salah satu ilmu dasar merupakan wahana pendidikan yang memuat aspek penalaran, mempunyai peranan penting dalam mewujudkan tujuan, fungsi dan tanggungjawab pendidikan. 
Penerapan sistem pembelajaran pada metode pembelajaran terbalik (reciprocal teaching) akan melatih siswa untuk belajar mandiri sehingga dibutuhkan persiapan yang mantap agar sesuai dengan tujuan yang ingin dicapai. Model pembelajaran yang efektif meliputi; mengajar siswa untuk belajar mengingat, berpikir, dan memotivasi diri sendiri. Hal ini berarti model pembelajaran sesungguhnya adalah model dimana guru dapat membantu siswa untuk memperoleh informasi, ide, keterampilan, cara berpikir, dan mengekspresikan dirinya sendiri.

Alternatif model pembelajaran yang dapat diterapkan adalah pembelajaran terbalik (Reciprocal Teaching). Pembelajaran terbalik (Reciprocal Teaching) sangat membantu dalam pengembangan pendidikan terutama dalam peningkatan hasil belajar siswa khususnya pada bidang matematika, karena dalam proses pembelajaran dengan menerapkan model pembelajaran terbalik siswa dituntut untuk betul-betul memahami dan mengkaji sendiri materi yang akan dibahas, kemudian setelah itu siswa akan menjelaskan sendiri kepada siswa yang lain. Dengan cara seperti ini siswa akan betul-betul serius dalam mempelajari materi yang ditugaskan oleh pengajar dan tidak merasa jenuh dalam proses pembelajarannya.

Salah satu materi yang diajarkan di SMA Muhammadiyah Al Amin Kota Sorong adalah materi "Bilangan Pecahan" dimana siswa dalam belajar lebih dominan daripada kegiatan guru dalam mengajar. Materi ini sering muncul dan digunakan dalam kehidupan sehari-hari. Untuk itu, dengan menerapkan metode pembelajaran terbalik dalam pembelajaran matematika disekolah diharapkan dapat meningkatkan pemahaman dan penguasaan siswa terhadap materi tersebut, karena pembelajaran dengan metode terbalik dirancang berawal dari masalah yang ada disekitar siswa dan berbasis pengetahuan yang telah dimilki siswa.

Berdasarkan uraian di atas, penelitian ini difokuskan pada metode pembelajaran terbalik (Reciprocal Teaching). Dalam penelitian ini akan diselidiki mengenai "Komparasi Hasil Belajar Matematika Antara Pembelajaran Terbalik (Reciprocal Teaching) dengan Pembelajaran Konvensional pada Siswa SMA Muhammadiyah Al Amin Kota Sorong

\section{Rumusan Masalah}

Berdasarkan latar belakang yang telah dikemukakan, maka masalah yang hendak diselidiki dalam penelitian adalah sebagai berikut:

1. Seberapa besar hasil belajar matematika yang dicapai siswa SMA Muhammadiyah Al Amin Kota Sorong dalam proses belajar mengajar melalui pembelajaran terbalik untuk materi pokok bilangan pecahan?

2. Seberapa besar hasil belajar matematika yang dicapai siswa SMA Muhammadiyah Al Amin Kota Sorong dalam proses belajar mengajar melalui metode konvensional 
untuk materi pokok bilangan pecahan?

3. Apakah hasil belajar matematika siswa SMA Muhammadiyah Al Amin Kota Sorong yang mengikuti pembelajaran terbalik lebih baik dibandingkan dengan hasil belajar matematika siswa yang mengikuti pembelajaran matematika konvensional untuk materi pokok bilangan pecahan?

\section{Tujuan Penelitian}

Adapun tujuan penelitian yang ingin dicapai dalam penelitian ini adalah sebagai berikut :

1. Untuk mengetahui seberapa besar hasil belajar matematika yang dicapai oleh siswa SMA Muhammadiyah Al Amin Kota Sorong dalam proses belajar mengajar melalui pembelajaran terbalik untuk materi pokok Bilangan Pecahan!

2. Untuk mengetahui seberapa besar hasil belajar matematika yang dicapai oleh siswa SMA Muhammadiyah Al Amin Kota Sorong dalam proses belajar mengajar melalui metode konvensional untuk materi pokok Bilangan Pecahan!

3. Untuk mengetahui apakah hasil belajar matematika siswa SMA Muhammadiyah Al Amin Kota Sorong dalam proses belajar mengajar melalui pembelajaran terbalik lebih baik dari hasil belajar matematika siswa melalui metode konvensional untuk materi pokok Bilangan Pecahan!

\section{TINJAUAN PUSTAKA}

\section{Belajar dan Pembelajaran \\ a. Pengertian Belajar}

Belajar merupakan proses kegiatan aktif yang ditandai dengan adanya perubahan yang terjadi pada siswa dalam membangun makna atau pemahaman. Istilah belajar berarti suatu proses perubahan sikap dan tingkah laku setelah terjadinya interaksi antara siswa dengan sumber belajar. Sumber belajar ini dapat berupa buku (sumber informasi lainnya), lingkungan (alam, sosial, budaya), guru atau sesama teman. Belajar banyak diartikan dan didefinisikan oleh para ahli dengan rumusan dan redaksi kalimat yang berbeda, tetapi pada hakekatnya prinsip dan tujuannya sama.

Slameto (1995:2) memberikan pengertian belajar sebagai berikut: "Belajar sebagai suatu proses usaha yang dilakukan seseorang untuk memperoleh suatu perubahan tingkah laku yang baru sebagai hasil pengalamannya sendiri dalam interaksi dengan lingkungan".

Hamalik (2001:36), menjelaskan bahwa: "Belajar adalah modifikasi atau memperteguh kelakuan melalui pengalaman ( learning is defined as the modification or strerngt lening of behavior trough experiencing".

Kemudian Sudjana (1989:5), mengemukakan bahwa: "Belajar adalah suatu proses yang ditandai dengan adanya perubahan pada diri seseorang “. Bertitik tolak dari berbagai pandangan beberapa ahli tersebut mengenai belajar, baik secara eksplisit maupun implisit diantara 
mereka terdapat kesamaan makna belajar, yaitu proses perubahan perilaku atau pribadi seseorang berdasarkan praktek atau pengalaman tertentu. Jadi jelas bahwa belajar itu membawa perubahan tingkah laku karena pengalaman dan latihan. Perubahan itu pada dasarnya didapatkannya kecakapan baru dan perubahan itu terjadi karena usaha yang di sengaja.

\section{b. Pengertian Belajar Matematika}

Salah satu karakateristik matematika adalah objek kajiannya yang abstrak. Oleh karena itu untuk mempelajari matematika diperlukan cara khusus yang tidak sama dengan mempelajari mata pelajaran lain. Berikut ini dipaparkan tentang bagaimana seharusnya belajar matematika.

Belajar matematika pada hakekatnya adalah proses pembelajaran yang berkenaan dengan ide-ide, struktur-struktur yang diatur menurut urutan logis. Belajar matematika tidak ada artinya kalau hanya dihafalkan saja. Belajar matematika baru bermakna bila dimengerti dan dipahami.

Hudoyo

(Mukhis,2005:15), mengemukakan bahwa: "Belajar matematika merupakan kegiatan mental yang tinggi, karena matematika berkaitan dengan ide-ide abstrak yang diberi simbol-simbol yang tersusun secara hirarkis dan penalarannya deduktif'. Untuk mempelajari matematika haruslah bertahap, berurutan serta berdasarkan pada pemahaman belajar yang lalu (sebelumnya). Proses belajar matematika akan terjadi dengan lancar bila dilakukan secara kontinu (rutin).

Suradi (2003 : 4), menjelaskan bahwa:

“ Belajar matematika pada hakekatnya merupakan suatu keaktifan mental atau kegiatan psikologis untuk memahami hubungan antara objek-objek dalam suatu struktur matematika serta berbagai hubungan antara struktur tersebut melalui manipulasi simbol sehingga diperoleh pengetahuan baru”.

Berdasarkan pendapat diatas, menunjukkan bahwa belajar matematika merupakan kegiatan mental yang tinggi, harus dilakukan secara berurutan, setapak demi setapak, kontinu, menggunakan pengalaman belajar sebelumnya, lebih mengutamakan pengertian dari pada hafalan dan siswa sebaiknya mengkostruksi (membangun) sendiri pengetahuannya melalui kegiatan aktif dalam belajar.

\section{c. Pengertian Pembelajaran}

\section{Matematika}

Pembelajaran merupakan proses komunikasi dua arah, yakni mengajar dilakukan oleh pihak guru sebagai pendidik atau murid sebagai anak didik. Penyelenggaraan pembelajaran merupakan salah satu tugas utama guru, dimana pembelajaran dapat diartikan sebagai kegiatan yang ditujukan untuk membelajarkan siswa dan merupakan suatu upaya yang memungkinkan siswa dapat belajar. Pembelajaran tidak hanya ditekankan pada academic skill (keterampilan 
akademik) tetapi juga pada life skill (keterampilan hidup) lainnya atau dapat dikatakan bahwa pembelajaran tidak hanya ditekankan pada aspek perkembangan pengetahuan saja (academic skill) namun juga pada kemampuan integrasi siswa, tanggungjawab siswa, kesabaran siswa, dan lain-lain.

Model pembelajaran dapat juga diasumsikan sebagai suatu perencanaan yang menggambarkan prosedur yang sistematik dalam proses pengorganisasian pengalaman belajar dan untuk mencapai tujuan belajar yang dapat digunakan oleh guru dalam merancang serta melaksanaan pembelajaran.

Dalam hubungannya dengan pelajaran matematika, maka dapat disimpulkan bahwa pembelajaran matematika adalah suatu upaya membantu siswa untuk mengkonstruksi (membangun) konsepkonsep atau prinsip-prinsip matematika dengan kemampuannya sendiri melalui proses internalisasi sehingga konsep atau prinsip itu terbangun kembali. Dengan demikian pembelajaran matematika dapat didefinisikan sebagai suatu proses membangun pemahaman siswa terhadap materi matematika.

\section{d. Hasil Belajar Matematika}

Dalam kamus bahasa Indonesia oleh Poerwardamirto (1982:256), hasil diartikan sebagai prestasi atau hasil yang telah dicapai dari apa yang telah dilakukan atau dikerjakan seseorang.

Untuk mengetahui sejauh mana tingkat keberhasilan siswa dalam menguasai bahan pelajaran yang telah dipelajari, diperlukan suatu alat ukur yang biasa digunakan untuk mengukur tingkat keberhasilan siswa terhadap penguasaan bahan pelajaran, yaitu berupa tes. Hasil belajar merupakan suatu ukuran berhasil tidaknya seorang siswa dalam proses belajar mengajar. Hasil belajar yang diperoleh siswa dapat menjadi indikator tentang batas kemampuan, kesanggupan, penguasaan siswa, tentang pengetahuan, keterampilan dan sikap atau nilai yang dimiliki dalam suatu pembelajaran. Dalam kaitannya dengan usaha belajar, hasil belajar ditentukan oleh tingkat penguasaan yang dicapai oleh siswa terhadap materi yang diajarkan setelah kegiatan belajar mengajar berlangsung dalam kurun waktu tertentu.

Dari uraian diatas dapat disimpulkan bahwa hasil belajar adalah kemampuan yang di peroleh siswa setelah melalui kegiatan belajar. Hasil belajar yang dicapai seseorang setelah mengikuti tes pada bidang studi matematika disebut hasil belajar matematika. Jadi hasil belajar matematika merupakan kemampuan atau penguasaan materi yang telah dikuasai oleh siswa setelah kegiatan belajar mengajar matematika sesuai dengan tujuan yang ingin dicapai.

\section{Model Pembelajaran Terbalik \\ a. Pengertian pembelajaran terbalik}

Pembelajaran terbalik (Reciprocal Teaching) adalah suatu proses pembelajaran untuk mengajarkan kepada siswa empat strategi pemahaman pengaturan diri yaitu merangkum materi, membuat 
pertanyaan, menjelaskan materi pelajaran serta dapat memprediksi pengembangan materi yang dipelajari agar siswa dapat memahami bacaan dengan baik. Ann Brown (Sakarani,2005:3), menyatakan bahwa pembelajaran terbalik yang diajarkan kepada siswa memiliki empat strategi pemahaman mandiri yang spesifik yaitu: merangkum, membuat pertanyaan, menjelaskan, dan memprediksikan. Keterampilan merangkum digunakan untuk mengubah permasalahan dalam kehidupan sehari-hari ke dalam model matematika. Keterampilan bertanya digunakan untuk menyelidiki apakah suatu permasalahan dapat diselesaikan atau tidak. Keterampilan menjelaskan digunakan untuk menjelaskan materi dengan kata-katanya sendiri. Sedangkan keterampilan memprediksi digunakan untuk meramalkan apa yang terjadi jika suatu syarat dihilangkan atau ditambahkan sebuah syarat pada suatu permasalahan. Pembelajaran terbalik lebih menghendaki guru untuk mengarahkan siswa dalam proses pembelajaran, artinya siswa dalam belajar lebih dominan daripada kegiatan guru dalam mengajar.

Palinesar dan Brown (dalam Nur,2000:16), mengemukakan bahwa metode pengajaran berdasarkan prinsip-prinsip pengajuan pertanyaan, yang mana keterampilan-keterampilan metakognitif diajarkan melalui pengajaran langsung dan pemodelan oleh guru untuk memperbaiki kinerja belajar siswa yang pemahamannya rendah dalam pembelajaran matematika. Pada kesempatan ini guru memodelkan perilaku tertentu untuk membantu siswa yang rendah hasil belajarnya dalam belajar memahami materi, dan melibatkan guru bekerja dengan siswa.

Palincsar (Nurbaeti,2005:10), pada pembelajaran terbalik terdapat empat strategi pembelajaran yaitu:

a. Siswa mempelajari dan merangkum materi yang diberikan oleh guru.

b. Siswa membuat pertanyaan yang berkaitan dengan materi yang dipelajari apabila dia tidak mampu memecahkan sendiri kemudian diajukan kepada guru.

c. Siswa harus mampu menjelaskan kembali isi materi yang dipelajari kepada rekannya.

d. Siswa dapat memprediksi kemungkinan pengembangan materi yang dipelajari saat itu.

Untuk mempelajari strategi ini, guru dan siswa membaca bacaan yang akan dibahas, kemudian guru memodelkan empat keterampilan tersebut dengan merangkum bacaan tersebut, menyajikan beberapa pertanyaan, mengklasifikasikan poinpoin berikutnya. Pada saat pembelajaran berlangsung situasinya terbalik, guru tidak lagi berperan untuk memberikan dukungan, umpan balik ketika siswa mempelajari materi tersebut.

Hal ini menunjukkan bahwa aktivitas pengajar dan peserta didik pada pembelajaran ini sangat berbeda dengan kondisi pembelajaran yang menggunakan model pembelajaran yang lain, seperti pembelajaran yang 
menggunakan metode ceramah, demonstrasi, ekspositori, inquiri dan lainnya. Namun metode ini hampir sama dengan metode penemuan dan metode belajar mandiri, hanya yang membedakan adalah pada metode pembelajaran terbalik, siswa dituntut untuk mengajarkan hasil temuannya kepada orang lain.

Model pembelajaran terbalik sangat erat kaitannya dengan metode pembelajaran mandiri yakni siswa lebih aktif mempelajari materi yang ada tanpa guru menjelaskan terlebih dahulu, akan tetapi guru juga harus mempunyai persiapan yang mantap sebelum pelaksanaan pembelajaran sebab apabila terdapat materi yang tidak mampu dipecahkan oleh siswa maka guru harus membantu untuk menjelaskannya.

\section{Pembelajaran Matematika Konvensional}

Istilah konvensional berarti apa yang sudah menjadi kebiasaan (tradisional). Pembelajaran matematika secara konvensional adalah proses pembelajaran yang biasa dilakukan disekolah, yaitu pembelajaran yang dimulai dengan pemaparan materi (definisi dan teorema) selanjutnya diberikan contoh soal dan terakhir evaluasi melalui soal latihan. Masalah kehidupan sehari-hari kadang-kadang digunakan pada materi tertentu tetapi hanya muncul dibagian akhir pembahasan atau saat pemberian contoh.

Pembelajaran matematika konvensional pada umumnya memiliki kekhasan tertentu, misalnya lebih mengutamakan hafalan daripada pengertian, menekankan keterampilan berhitung, mengutamakan hasil daripada proses dan pengajaran masih berpusat kepada guru. Dengan demikian guru masih mendominasi proses mengajar belajar di kelas dengan kata lain siswa cenderung pasif. Kebanyakan siswa hanya mendengar dan menulis dengan tekun itupun terbatas pada penjelasan guru yang kurang dimengerti siswa.

\section{HIPOTESIS}

Berdasarkan tinjauan pustaka dan kerangka berpikir, maka hipotesis yang diangkat dalam penelitian ini adalah

" Hasil belajar siswa dengan model pembelajaran terbalik lebih baik dibandingkan dengan hasil belajar siswa yang mengikuti pembelajaran matematika secara konvensional untuk materi pokok bilangan pecahan".

Secara statistik hipotesis ini dirumuskan sebagai berikut :

$$
\text { Ho : } \mu_{1}=\mu_{2} \text { lawan } \mathrm{H}_{1}: \mu_{1}>
$$
$\mu_{2}$

Keterangan :

$\mu_{1}=$ Parameter skor rata -rata hasil belajar matematika siswa yang diajar dengan pembelajaran terbalik pada SMA Muhammadiyah Al Amin Kota Sorong.

$\mu_{2}=$ Parameter skor rata-rata hasil belajar matematika siswa yang diajar dengan metode konvensional pada SMA Muhammadiyah Al Amin Kota Sorong. 


\section{METODE PENELITIAN}

\section{Jenis Penelitian}

Penelitian ini adalah penelitian eksperimen. Satu kelas sebagai kelas eksperimen dan satu kelas sebagai kelas kontrol. Kelas eksperimen diberi perlakuan pembelajaran matematika dengan menggunakan metode pembelajaran terbalik. Kelas kontrol diberi perlakuan pembelajaran matematika konvensional.

\section{Variabel Penelitian}

Variabel yang akan diteliti terdiri dari dua jenis, yaitu variabel bebas dan variabel terikat. Hasil belajar matematika siswa pada mata pelajaran matematika sebagai variabel bebas dan metode mengajar sebagai variabel terikat, metode mengajar yang akan diterapkan pada pengajaran matematika terdiri dari dua, yaitu metode pembelajaran terbalik (diterapkan pada kelas eksperimen) dan metode konvensional (diterapkan pada kelas kontrol).

\section{Definisi Operasional Variabel}

1. Hasil belajar matematika dalam penelitian ini adalah hasil belajar matematika siswa SMA Muhammadiyah Al Amin Kota Sorong tahun ajaran 2015/2016 yang diperoleh dari skor tes prestasi belajar matematika yang diberikan kepada siswa.

2. Pembelajaran terbalik (Reciprocal Teaching) adalah suatu proses pembelajaran untuk mengajarkan kepada siswa empat strategi pemahaman pengaturan diri yaitu merangkum materi, membuat pertanyaan, menjelaskan materi serta dapat memprediksi pengembangan materi yang dipelajari agar siswa dapat memahami bacaan dengan baik. Pembelajaran terbalik lebih menghendaki guru untuk mengarahkan dalam proses pembelajaran.

3. Pembelajaran matematika konvensional adalah proses pembelajaran yang biasa dilakukan di sekolah, yaitu pembelajaran yang dimulai dengan pemaparan materi (definisi dan teorema) selanjutnya diberikan contoh soal dan terakhir evaluasi melalui soal latihan.

\section{Populasi dan Sampel}

1. Populasi

Penelitian ini dilaksanakan di SMA Muhammadiyah Al Amin Kota SorongKota Sorong tahun ajaran 2015 / 2016. Populasi penelitian ini adalah seluruh siswa SMA Muhammadiyah Al Amin Kota Sorong

2. Sampel

Teknik pengambilan sampel yang dilaksanakan pada penelitian ini adalah teknik sampel jenuh. sampel adalah SMA Muhammadiyah Al Amin Kota Sorong Kelas eksperimen diberi perlakuan pembelajaran matematika menggunakan metode pembelajaran terbalik. Kelas kontrol diberi perlakuan pembelajaran matematika konvensional pada materi pelajaran yang sama. 


\section{Rancangan Penelitian}

Sesuai dengan jenis penelitian yang dikemukakan di atas, maka rancangan penelitian ini adalah Test Only Control Group dengan skema sebagai berikut, berikut:

\begin{tabular}{|c|c|c|c|}
\hline Random & Kelompok & Perlakuan & $\begin{array}{c}\text { Hasil } \\
\text { Penelitian }\end{array}$ \\
\hline $\mathrm{R}$ & $\mathrm{E}$ & $\mathrm{T}_{1}$ & $\mathrm{Q}_{1}$ \\
\hline $\mathrm{R}$ & $\mathrm{K}$ & $\mathrm{T}_{2}$ & $\mathrm{Q}_{1}$ \\
\hline
\end{tabular}

Keterangan :

$\mathrm{R}$ : Proses pengambilan sampel secara random

E : Kelompok eksperimen

K : Kelompok kontrol

$\mathrm{T}_{1}$ : Perlakuan dengan menggunakan pembelajaran terbalik

$\mathrm{T}_{2}$ : Perlakuan dengan metode konvensional

$\mathrm{Q}_{1}$ : Observasi setelah perlakuan untuk kelas eksperimen

$\mathrm{Q}_{2} \quad$ : Obsevasi setelah perlakuan untuk kelas kontrol.

\section{Pelaksanaan Eksperimen}

1. Langkah-langkah kegiatan pembelajaran pada kelompok eksperimen sebagai berikut:

1). Guru menuliskan pokok bahasan/sub pokok bahasan materi yang akan dibahas.
2). Guru menginformasikan tujuan pembelajaran awal bahwa pembelajaran ini bertujuan menanamkan strategi pemahaman mandiri yang khusus dan ditunjuk seorang siswa untuk tampil mengajar didepan temannya yang lain.

3). Guru memberikan petunjuk-petunjuk yang harus dilakukan siswa pada saat pembelajaran berlangsung.

4). Siswa melaksanakan tugas sebagai berikut:

a. Mempelajari materi yang ditugaskan oleh guru secara mandiri selanjutnya meringkas materi tersebut.

b. Membuat pertanyaan yang berkaitan dengan materi yang diringkasnya.

c. Siswa mejelaskan kembali isi materi yang telah ditugaskan oleh guru.

d. Siswa mampu memprediksi kemungkinan pengembangan materi yang ditugaskan oleh guru.

5). Guru mengevaluasi aktivitas siswa dengan 

memberikan pertanyaan lisan pada siswa, kemudian guru menandai sejumlah siswa yang benar secara meyakinkan.
6). Guru menyuruh beberapa siswa untuk menjelaskan hasil temuannya pada saat belajar mandiri di depan kelas.

7). Guru memandu proses pembelajaran dengan memberikan

kesempatan siswa yang lain untuk menanggapi materi yang telah disampaikan oleh temannya.

8). Guru mengungkapkan kembali pengembangan materi dengan metode tanya jawab untuk melihat pemahaman siswa yang lain.

9). Guru mencatat semua aktifitas dalam proses pembelajaran pada lembar observasi.

10). Guru memberikan tes kepada siswa.

11). Guru melakukan evaluasi diri atau refleksi untuk mengamati

keberhasilan penerapan pembelajaran terbalik yang telah dilakukan.

2. Langkah umum kegiatan pembelajaran dengan metode konvensional pada siswa SMA
Muhammadiyah Al Amin Kota Sorong.

Menetapkan masalah

a. Menyampaikan Tujuan Instruksional Khusus (TIK)

b. Menjelaskan materi

c. Memberikan contoh

d. Memberikan kesempatan kepada siswa untuk bertanya

e. Menjawab pertanyaan siswa

f. Memberikan soal latihan

g. Memberikan kesempatan pada siswa untuk mencatat

h. Memberikan soal pekerjaan / PR

\section{Instrumen Penelitian}

Untuk mengumpulkan data dalam rangka eksperimen, digunakan instrumen yang telah digunakan pada tahap uji tes hasil belajar. Instrumen penelitian ini terdiri dari lembar observasi (pengamatan), tes hasil belajar yang masing-masing akan digunakan untuk mengumpulkan data sebagai hasil instrumen penelitian. Secara singkat instrumen penelitian tersebut diuraikan sebagai berikut:

a. Lembar Observasi (pengamatan)

Lembar observasi digunakan untuk memperoleh data yang berkaitan dengan kegiatan belajar mengajar selama penelitian, yaitu lembar pengamatan aktifitas siswa. Lembar pengamatan siswa ini befungsi untuk memperoleh data tentang aktivitas siswa selama pembelajaran,

dengan 
menggunakan instrumen berupa lembar pengamatan aktivitas siswa.

b. Tes Hasil Belajar

Tes hasil belajar digunakan untuk memperoleh informasi tentang kemampuan awal siswa sebelum proses pembelajaran serta penguasaan siswa terhadap materi pokok bilangan pecahan setelah proses pembelajaran. Tes hasil belajar yang digunakan pada tahap eksperimen merupakan bentuk essay/uraian yang dikembangkan oleh penulis dan dilengkapi dengan kisi-kisi tes hasil belajar yang telah divalidasi oleh beberapa Dosen Jurusan Pendidikan Matematika Universitas Muhammadiyah Sorong serta beberapa guru matematika SMA Al Amin Kota Sorong (dapat dilihat dalam lampiran D).

Kriteria yang digunakan untuk menentukan kategori skor hasil belajar matematika yang diterapkan oleh Depdikbud (2005), sebagai berikut:

$0 \%$ - 34\% dikategorikan sangat rendah

$35 \%-54 \%$ dikategorikan rendah

$55 \%-64 \%$ dikategorikan sedang

$65 \%-84 \%$ dikategorikan tinggi

$85 \%$ - $100 \%$ dikategorikan sangat tinggi

\section{Teknik Pengumpulan Data}

Sesuai dengan rencana eksperimen penelitian, maka data dalam penelitian ini akan dikumpulkan dengan cara sebagai berikut:

a. Data observasi (pengamatan)

Data observasi ini dilaksanakan langsung oleh penulis dengan menggunakan lembar observasi dengan cara mengamati sesuai dengan keadaan siswa yang diamati.

b. Data Hasil Belajar

Data hasil belajar siswa dikumpulkan melalui pemberian tes, yakni pretes diberikan sebelum proses pembelajaran berlangsung dan postes diberikan setelah proses pembelajaran pada kelas eksperimen dan kelas kontrol. Pengawasan dilakukan secara langsung oleh penulis dan kerjasama dengan guru bidang studi matematika itu sendiri.

\section{Teknik Analisis Data}

Data yang terkumpul dalam penelitian ini diolah dan dianalisis dengan menggunakan analisis statistik deskriptif dan analisis statistik inferensial. Analisis statistik deskriptif digunakan untuk mendiskripsikan hasil belajar responden pada materi pokok bilangan pecahan. Sedangkan analisis inferensial digunakan untuk menguji perbedaan hasil belajar siswa yang menggunakan pendekatan pembelajaran terbalik (reciprocal teaching) dengan pendekatan pembelajaran konvensional.

a. Analisis Statistik Deskriptif Statistik deskriptif digunakan untuk mendeskripsikan skor karakteristik responden. Untuk keperluan tersebut digunakan tabel distribusi frekuensi, ratarata dan standar deviasi.

b. Analisis Statistik Inferensial Statistik inferensial digunakan untuk menguji hipotesis penelitian, untuk keperluan 
tersebut digunakan statistik ujit.

\section{HASIL PENELITIAN}

HASIL

PELAKSANAAN

\section{EKSPERIMEN}

1. Hasil Tes untuk Mengetahui Hasil Belajar Siswa Terhadap Materi Bilangan Pecahan Melalui Pembelajaran Terbalik (Reciprocal Teaching) dan Pembelajaran Konvensional.

a) Analisis Hasil Deskriptif Tes

Berdasarkan hasil analisis deskriptif sebagaimana tercantum pada lampiran $\mathrm{C}$, maka rangkuman statistik skor hasil belajar siswa SMA Muhammadiyah Al Amin Kota Sorong pada pokok bahasan Bilangan Pecahan, diperoleh karekteristik nilai responden untuk masing-masing kelompok siswa yang diajarkan melalui pendekatan pembelajaran terbalik dan pembelajaran konvensional.

a. Deskripsi karakteristik nilai kelompok siswa yang diajarkan melalui pembelajaran terbalik (Reciprocal Teaching).

Dari hasil analisis deskriptif sebagaimana yang terlampir dalam lampiran $\mathrm{C}$ maka statistik skor hasil belajar pada pokok bahasan bilangan pecahan yang diajarkan dengan menggunakan pembelajaran terbalik dapat dirangkum dalam tabel sebagai berikut:
Tabel 4.1: Deskripsi Nilai Hasil

Belajar Bilangan

Pecahan Kelompok

yang Diajarkan

Melalui Pembelajaran

Terbalik (reciprocal teaching).

\begin{tabular}{|c|l|c|}
\hline No & Statistik & $\begin{array}{c}\text { Nilai } \\
\text { Statistik }\end{array}$ \\
\hline 1 & Ukuran & 38 \\
2 & sampel & 100,00 \\
3 & Skor Ideal & 90.00 \\
4 & Skor & 65,00 \\
5 & Maksimum & 75,79 \\
6 & Skor & 25.00 \\
7 & Minimum & 31,79 \\
8 & Rata-rata & 5,64 \\
& Skor & \\
& Range Skor & \\
& Varians & \\
& Standar & \\
& Deviasi & \\
\hline
\end{tabular}

Berdasarkan tabel diatas dapat dilihat bahwa skor rata-rata hasil belajar siswa SMA Muhammadiyah Al Amin Kota Sorong pada pokok bahasan pecahan setelah diberikan pembelajaran terbalik adalah sebesar 75,79 dengan standar deviasi 5,64. Skor yang dicapai responden maksimum dari skor minimum 65 yang mungkin dicapai 0 sampai skor maksimun 90 dari skor ideal yang mungkin dicapai 100. Dengan rentang skor 25. Hal ini menunjukkan bahwa hasil belajar siswa cukup bervariasi.

Jika skor hasil belajar bilangan pecahan pada siswa dikelompokkan ke dalam lima kategori, maka diperoleh 
distribusi frekuensi dan persentase sebagai berikut:

Tabel 4.2:Distribusi Frekuensi dan Persentase Hasil Belajar Bilangan Pecahan Kelompok yang Diajarkan Melalui Pembelajaran Terbalik (reciprocal teaching).

\begin{tabular}{|c|c|c|c|}
\hline Skor & $\begin{array}{c}\text { Katego } \\
\text { ri }\end{array}$ & $\begin{array}{c}\text { Freku } \\
\text { ensi }\end{array}$ & $\begin{array}{l}\text { Persent } \\
\text { ase (\%) }\end{array}$ \\
\hline $0,00-$ & Sangat & 0 & 0,00 \\
\hline 34,00 & rendah & 0 & 0,00 \\
\hline $35,00-$ & Rendah & 0 & 0,00 \\
\hline 54,00 & Sedang & 34 & 89,47 \\
\hline $55,00-$ & Tinggi & 4 & 10,53 \\
\hline 64,00 & Sangat & & \\
\hline 65,00- & tinggi & & \\
\hline 84,00 & & & \\
\hline $85,00-$ & & & \\
\hline 100,00 & & & \\
\hline \multicolumn{2}{|c|}{ Jumla } & 38 & 100,00 \\
\hline
\end{tabular}

Dari tabel 4.2 menunjukkan bahwa persentase skor hasil belajar siswa terhadap pokok bahasan bilangan pecahan setelah diajarkan pembelajaran terbalik sebesar 0,00\% yang berada dalam kategori sangat rendah. Paling banyak siswa dengan persentase $89,47 \%$ berada pada kategori tinggi. Disamping itu sesuai dengan skor rata-rata hasil belajar kelompok siswa terhadap bilangan pecahan sebesar 75,79. Jika dikonversi kedalam tabel ternyata berada dalam kategori tinggi dari skor yang mungkin dicapai yaitu 100. Hal ini berarti bahwa rata-rata hasil belajar siswa SMA Muhammadiyah Al Amin Kota
Sorong, setelah melalui pembelajaran terbalik berada dalam kategori tinggi.

b. Deskripsi karakteristik nilai kelompok siswa yang diajarkan melalui pembelajaran konvensional.

Dari hasil analisis deskriptif sebagaimana yang terlampir dalam lampiran $\mathrm{C}$ maka statistik skor hasil belajar pada pokok bahasan bilangan pecahan yang diajar dengan menggunakan pembelajaran konvensional dapat dirangkum dalam tabel sebagai berikut:

Tabel 4.3: Deskripsi Nilai Hasil Belajar Bilangan Pecahan Kelompok yang Diajarkan Melalui Pembelajaran Konvensional.

\begin{tabular}{|c|c|c|}
\hline $\begin{array}{l}\mathbf{0} \\
\mathbf{0}\end{array}$ & Statistik & $\begin{array}{c}\text { Nilai } \\
\text { Statistik }\end{array}$ \\
\hline 1 & Ukuran & 37 \\
\hline 2 & sampel & 100.00 \\
\hline 3 & Skor Ideal & 75,00 \\
\hline 4 & Skor & 35,00 \\
\hline 5 & Maksimum & 54,87 \\
\hline 6 & Skor & 40,00 \\
\hline 7 & Minimum & 106,18 \\
\hline & Rata-rata & 10,30 \\
\hline 8 & Skor & \\
\hline & Range Skor & \\
\hline & Varians & \\
\hline & Standar & \\
\hline & Deviasi & \\
\hline
\end{tabular}

Berdasarkan tabel 4.3 dapat dilihat bahwa skor rata-rata hasil belajar siswa SMA Muhammadiyah Al 
Amin Kota SorongKota Sorong pada pokok bahasan pecahan setelah diajarkan melalui pembelajaran konvensional adalah sebesar 54,87 dengan standar deviasi 10,30 Skor yang dicapai responden maksimum dari skor minimum 35 yang mungkin dicapai 0 sampai skor maksimun 75 dari skor ideal yang mungkin dicapai 100. Dengan rentang skor 40. Hal ini menunjukkan bahwa hasil belajar siswa cukup bervariasi.

Jika skor hasil belajar bilangan pecahan pada siswa dikelompokkan ke dalam lima kategori, maka diperoleh distribusi frekuensi dan persentase sebagai berikut:

Tabel 4.4:Distribusi Frekuensi dan Persentase Hasil Belajar Bilangan Pecahan Kelompok yang Diajar Melalui Pembelajaran Konvensional.

\begin{tabular}{|c|c|c|c|}
\hline Skor & Kategori & $\begin{array}{l}\text { Frek } \\
\text { uensi }\end{array}$ & $\begin{array}{c}\text { Perse } \\
\text { ntase } \\
(\%)\end{array}$ \\
\hline $\begin{array}{c}0,00- \\
34,00\end{array}$ & $\begin{array}{l}\text { Sangat } \\
\text { rendah }\end{array}$ & 0 & 0,00 \\
\hline $\begin{array}{l}35,00- \\
54,00\end{array}$ & Rendah & 16 & 43,24 \\
\hline $\begin{array}{l}55,00- \\
64,00\end{array}$ & Sedang & 14 & 37,84 \\
\hline $\begin{array}{l}65,00- \\
84,00\end{array}$ & Tinggi & 7 & 18,92 \\
\hline $\begin{array}{l}85,00- \\
100,00 \\
\end{array}$ & $\begin{array}{l}\text { Sangat } \\
\text { tinggi }\end{array}$ & 0 & 0,00 \\
\hline \multicolumn{2}{|c|}{ Jumlah } & 37 & $\begin{array}{c}100,0 \\
0\end{array}$ \\
\hline
\end{tabular}

Dari tabel 4.4 menunjukkan bahwa persentase skor hasil belajar siswa terhadap pokok bahasan bilangan pecahan setelah diajarkan pembelajaran konvensional sebesar $0,00 \%$ yang berada dalam kategori sangat rendah. Paling banyak siswa dengan persentase $43,24 \%$ berada pada kategori rendah. Disamping itu sesuai dengan skor rata-rata hasil belajar kelompok siswa terhadap bilangan pecahan sebesar 54,87. Jika dikonversi kedalam tabel ternyata berada dalam kategori sedang dari skor yang mungkin dicapai yaitu 100. Hal ini berarti bahwa rata-rata hasil belajar siswa SMA Muhammadiyah Al Amin Kota Sorong setelah melalui pembelajaran konvensional berada dalam kategori sedang.

\section{Analisis Hasil Inferensial Tes}

a. Pengujian Persyaratan Analisis

Sebelum mengadakan uji statistik inferensial yaitu dengan menggunakan statistik uji-t, maka terlebih dahulu dilakukan pengujian persyaratan analisis sebagai berikut:

1. Uji Normalitas

Pengujian normalitas bertujuan untuk melihat apakah data tentang hasil belajar bilangan pecahan pada masing-masing kelompok perlakuan berasal dari populasi yang berdistribusi normal.

Hasil pengujian normalitas pada perlakuan dapat dilihat pada lampiran $\mathrm{C}$, menunjukkan bahwa nilai $\mathrm{P}=$ 0,067 dan $\alpha=0,05$ berarti nilai $\mathrm{P}>\alpha$, maka dapat disimpulkan bahwa data hasil belajar matematika pada 
pokok bahasan pecahan dari kedua kelompok perlakuan berasal dari populasi yang berdistribusi normal.

2. Uji Kesamaan Varians

Untuk uji kesamaan varians hasil uji hipotesis dengan menggunakan uji-t memberikan nilai untuk data yang mempunyai varians yang sama dan data yang mempunyai varians yang tidak sama, sehingga berdasarkan uji varians pada lampiran diperoleh $\mathrm{P}=0,009$ yang lebih kecil dari $\alpha=0,05$ berarti nilai $\mathrm{P}<\alpha$, maka nilai Probabilitas yang diambil pada pengujian hipotesis adalah pada varians yang tidak sama.

b. Pengujian Hipotesis Penelitian

Dari hasil analisis inferensial yaitu dengan uji-t pada lampiran $\mathrm{C}$ menunjukkan bahwa $\mathrm{P}=0,000$ dengan taraf signifikan $\alpha=0,05$. Hasil ini menunjukkan bahwa $\mathrm{P}<\alpha$ (nilai $\mathrm{P}$ lebih rendah dari pada nilai $\alpha$ ). Hal ini berarti bahwa hipotesis Ho ditolak dan $\mathrm{H}_{1}$ diterima sehingga dapat disimpulkan bahwa hasil belajar siswa dengan model pembelajaran terbalik (reciprocal teaching) lebih baik dibandingkan dengan hasil belajar siswa yang mengikuti pembelajaran matematika secara konvensional untuk materi pokok bilangan pecahan pada siswa SMA
Muhammadiyah Al Amin Kota Sorong

Hasil Observasi untuk
Mengetahui Aktivitas Siswa
dalam Proses
Melalui Pembelajar Mengajar
Meciprocal Teaching) dan
Pembelajaran Konvensional.

Untuk mengetahui aktivitas siswa selama proses belajar mengajar dapat kita lihat pada hasil observasi yang dilakukan pada setiap pertemuan. Pada setiap pertemuan dicatat berapa jumlah siswa yang hadir, mengajukan pertanyaan, acuh tak acuh melakukan pekerjaan lain pada saat proses belajar mengajar, memperhatikan guru, berani mengajukan diri mengerjakan soal dipapan tulis, aktif dalam kerja kelompok dan mengerjakan tugas pekerjaan rumah. Hasil tersebut secara ringkas disajikan dalam tabel 4.5 mengenai Aktivitas Siswa SMA Muhammadiyah Al Amin Kota Sorong untuk kelas eksperimen selama proses belajar mengajar berlangsung, sedangkan secara terperinci dapat dilihat dalam lampiran B.

Tabel 4.5: Aktivitas Siswa SMA Muhammadiyah Al Amin Kota Sorong Selama Proses Belajar Mengajar 
NO

KATEGORI

Frekuensi Aktifitas Siswa

PENGAMATAN

\begin{tabular}{cl}
\hline 1 & Siswa yang hadir \\
\hline 2 & $\begin{array}{l}\text { Siswa yang mengajukan } \\
\text { pertanyaan }\end{array}$ \\
\hline 3 & $\begin{array}{l}\text { Siswa yang memberikan } \\
\text { komentar }\end{array}$ \\
\hline 4 & $\begin{array}{l}\text { Siswa yang berani menjawab } \\
\text { pertanyaan lisan guru }\end{array}$ \\
\hline 5 & Siswa yang acuh tak acuh \\
\hline 6 & $\begin{array}{l}\text { Siswa yang melakukan } \\
\text { kegiatan lain pada saat proses } \\
\text { belajar mengajar }\end{array}$ \\
\hline 7 & $\begin{array}{l}\text { Siswa yang serius } \\
\text { memperhatikan materi }\end{array}$ \\
\hline 8 & $\begin{array}{l}\text { Siswa yang berani } \\
\text { mengerjakan soal latihan } \\
\text { dipapan tulis }\end{array}$ \\
\hline 9 & $\begin{array}{l}\text { Siswa yang aktif dalam kerja } \\
\text { kelompok }\end{array}$ \\
\hline 10 & $\begin{array}{l}\text { Siswa yang mengerjakan tugas } \\
\text { PR }\end{array}$ \\
&
\end{tabular}

Dari tabel 4.5.di atas dapat dilihat mengenai keadaan setiap siswa pada setiap indikator yang diamati. Banyaknya siswa yang hadir bervariasi, berkisar antara 36-38 dari 38 siswa. Banyaknya siswa yang mengajukan pertanyaan pada pertemuan pertama sebanyak 5 siswa menjadi 17 pada pertemuan terakhir dari 38 siswa yang hadir. Banyaknya siswa yang memberikan komentar/tanggapan pada pertemuan pertama sebanyak 8 siswa menjadi 19 siswa dari 38 siswa yang hadir pada pertemuan terakhir. Banyaknya siswa yang berani menjawab pertanyan lisan

\begin{tabular}{|c|c|c|c|c|c|c|c|c|c|}
\hline & & Fre & kuen & si $\mathbf{A}$ & stifit & as $\mathrm{S}$ & & & \\
\hline 1 & 2 & 3 & 4 & 5 & 6 & 7 & 8 & 9 & 10 \\
\hline & 38 & 36 & 37 & 38 & 37 & 37 & 38 & 38 & \\
\hline & 5 & 5 & 8 & 8 & 10 & 12 & 15 & 17 & \\
\hline & 8 & 8 & 10 & 12 & 12 & 14 & 16 & 19 & \\
\hline & 8 & 10 & 13 & 15 & 18 & 20 & 22 & 24 & \\
\hline & 7 & 6 & 4 & 3 & 3 & 2 & 2 & 2 & $\mathrm{~T}$ \\
\hline $\begin{array}{l}\mathrm{E} \\
\mathrm{S}\end{array}$ & 6 & 5 & 4 & 3 & 3 & 2 & 1 & 1 & \\
\hline W & 20 & 23 & 28 & 30 & 30 & 32 & 34 & 36 & \\
\hline $\mathrm{L}$ & 4 & 6 & 10 & 12 & 12 & 14 & 17 & 17 & $\mathrm{R}$ \\
\hline & 25 & 26 & 29 & 31 & 31 & 32 & 33 & 35 & \\
\hline & 29 & 31 & 33 & 33 & 34 & 35 & 35 & 37 & \\
\hline
\end{tabular}

guru pada pertemuan pertama sebanyak 8 siswa menjadi 24 siswa pada pertemuan terakhir dari 38 siswa yang hadir. Banyaknya siswa yang acuh tak acuh pada proses belajar mengajar pada pertemuan pertama sebanyak 7 siswa menjadi 2 siswa dari 38 siswa yang hadir. Banyaknya siswa yang melakukan kegiatan lain pada saat proses belajar mengajar sebanyak 6 siswa menjadi 1 siswa dari 38 siswa yang hadir. Banyaknnya siswa yang serius memperhatikan materi pada pertemuan pertama sebanyak 20 siswa menjadi 36 siswa dari 38 siswa yang hadir pada pertemuan terakhir. 
Banyaknya siswa yang berani mengajukan diri mengerjakan soal dipapan tulis pada pertemuan pertama sebanyak 4 siswa menjadi 17 siswa dari 38 siswa yang hadir. Banyaknya siswa yang aktif dalam kerja kelompok pada pertemuan pertama sebanyak 25 siswa menjadi 35 siswa dari 38 siswa yag hadir. Banyaknya siswa yang mengerjakan tugas PR pada pertemuan pertama sebanyak 29 siswa menjadi 37 siswa dari 38 siswa yang hadir pada pertemuan terakhir.

Kemudian dalam tabel 4.6, secara ringkas dijelaskan mengenai aktivitas siswa SMA Muhammadiyah Al Amin Kota Sorong (kelas kontrol) selama proses belajar mengajar berlangsung (lampiran B):

Tabel 4.6: Aktivitas siswa SMA Muhammadiyah Al Amin Kota Sorong Selama Proses Belajar Mengajar

NO

Frekuensi Aktifitas Siswa

\begin{tabular}{ll}
\multicolumn{2}{c}{ KATEGORI } \\
\multicolumn{1}{c}{ PENGAMATAN } \\
\hline 1 & Siswa yang hadir \\
\hline 2 & $\begin{array}{l}\text { Siswa yang mengajukan } \\
\text { pertanyaan }\end{array}$ \\
\hline 3 & $\begin{array}{l}\text { Siswa yang memberikan } \\
\text { komentar }\end{array}$ \\
\hline 4 & $\begin{array}{l}\text { Siswa yang berani menjawab } \\
\text { pertanyaan lisan guru }\end{array}$ \\
\hline 5 & Siswa yang acuh tak acuh \\
\hline 6 & $\begin{array}{l}\text { Siswa yang melakukan } \\
\text { kegiatan lain pada saat proses } \\
\text { belajar mengajar }\end{array}$ \\
\hline 7 & $\begin{array}{l}\text { Siswa yang } \\
\text { memperhatikan materi }\end{array}$ \\
\hline 8 & $\begin{array}{l}\text { Siswa yang berani } \\
\text { mengerjakan soal latihan } \\
\text { dipapan tulis }\end{array}$ \\
\hline 9 & $\begin{array}{l}\text { Siswa yang aktif dalam kerja } \\
\text { kelompok }\end{array}$ \\
\hline 10 & $\begin{array}{l}\text { Siswa yang mengerjakan tugas } \\
\text { PR }\end{array}$
\end{tabular}

Dari tabel 4.6 di atas dapat dilihat mengenai keadaan setiap siswa kelas

\begin{tabular}{llllllllll}
\hline 1 & 2 & 3 & 4 & 5 & 6 & 7 & 8 & 9 & 10
\end{tabular}

\begin{tabular}{llllllll}
35 & 37 & 36 & 36 & 37 & 37 & 35 & 37 \\
\hline 5 & 7 & 7 & 5 & 10 & 8 & 10 & 14
\end{tabular}

\begin{tabular}{llllllll}
\hline 4 & 8 & 7 & 10 & 12 & 15 & 12 & 18
\end{tabular}

$\begin{array}{llllllll}5 & 8 & 10 & 12 & 9 & 10 & 13 & 18\end{array}$

\begin{tabular}{llllllllll} 
& \multicolumn{1}{c}{6} & 6 & 5 & 4 & 3 & 3 & 2 & 2 & $\mathrm{~T}$ \\
$\mathrm{n}$ & 8 & 6 & 8 & 5 & 7 & 5 & 5 & 4 & $\mathrm{E}$ \\
$\mathrm{E}$ & & & & & & & & & $\mathrm{S}$ \\
$\mathrm{S}$ & & & & & & & & & $\mathrm{A}$ \\
$\mathrm{A}$ & & & & & & & & & $\mathrm{K}$ \\
$\mathrm{W}$ & 10 & 9 & 15 & 15 & 18 & 20 & 22 & 25 & $\mathrm{H}$ \\
$\mathrm{A}$ & & & & & & & & & $\mathrm{I}$ \\
$\mathrm{L}$ & 4 & 4 & 7 & 10 & 14 & 15 & 15 & 17 & $\mathrm{R}$
\end{tabular}

\begin{tabular}{llllllll}
\hline 6 & 9 & 13 & 15 & 18 & 18 & 20 & 21 \\
\hline 5 & 9 & 9 & 8 & 15 & 13 & 18 & 25
\end{tabular}

kontrol pada setiap indikator yang diamati. Banyaknya siswa yang hadir 
bervariasi, berkisar antara 35-37 dari 37 siswa. Banyaknya siswa yang mengajukan pertanyaan pada pertemuan pertama sebanyak 5 siswa menjadi 14 pada pertemuan terakhir dari 37 siswa yang hadir. Banyaknya siswa yang memberikan komentar/tanggapan pada pertemuan pertama sebanyak 4 siswa menjadi 18 siswa dari 37 siswa yang hadir pada pertemuan terakhir. Banyaknya siswa yang berani menjawab pertanyan lisan guru pada pertemuan pertama sebanyak 5 siswa menjadi 18 siswa pada pertemuan terakhir dari 37 siswa yang hadir. Banyaknya siswa yang acuh tak acuh pada proses belajar mengajar pada pertemuan pertama sebanyak 6 siswa menjadi 2 siswa dari 37 siswa yang hadir. Banyaknya siswa yang melakukan kegiatan lain pada saat proses belajar mengajar sebanyak 8 siswa menjadi 4 siswa dari 37 siswa yang hadir. Banyaknnya siswa yang serius memperhatikan materi pada pertemuan pertama sebanyak 10 siswa menjadi 25 siswa dari 37 siswa yang hadir pada pertemuan terakhir. Banyaknya siswa yang berani mengajukan diri mengerjakan soal dipapan tulis pada pertemuan pertama sebanyak 2 siswa menjadi 17 siswa dari 37 siswa yang hadir. Banyaknya siswa yang aktif dalam kerja kelompok pada pertemuan pertama sebanyak 6 siswa menjadi 21 siswa dari 37 siswa yag hadir. Banyaknya siswa yang mengerjakan tugas PR pada pertemuan pertama sebanyak 5 siswa menjadi 25 siswa dari 37 siswa yang hadir pada pertemuan terakhir.

Hasil observasi siswa menunjukkan bahwa terjadi perbedaan aktivitas disetiap kelas dengan memperhatikan indikator yang diamati. Hal ini dilihat mulai dari pertemuan pertama sampai pertemuan terakhir yaitu kehadiran siswa, perhatian siswa pada materi dan guru, motivasi siswa, keaktifan siswa dan kedisiplinan siswa dalam mengerjakan tugas/PR pada kelas eksperimen mengalami peningkatan bila dibandingkan dengan kelas kontrol cukup bervariasi aktivitas yang dilakukan oleh siswa dalam proses belajar mengajar. Dapat disimpulkan bahwa metode pembelajaran terbalik (reciprocal teaching) dapat mengubah aktivitas siswa dalam belajar menjadi lebih tertarik terhadap matematika.

\section{PEMBAHASAN}

Mengacu pada tinjauan pustaka dan kerangka berpikir dalam hasil penelitian yang diperoleh, maka pada bagian ini dikemukakan pembahasan hasil penelitian.

1. Hasil Analisis Statistik Deskriptif Hasil analisis deskriptif menunjukkan bahwa hasil belajar matematika siswa SMA Muhammadiyah Al Amin Kota Sorong yang diajar dengan menggunakan sistem pembelajaran terbalik pada pokok bahasan pecahan berada pada kategori tinggi. Dari 38 siswa pada kelompok ini terdapat $\mathbf{1 0 , 5 3 \%}$ siswa yang memiliki hasil belajar matematika dalam kategori sangat tinggi, $\mathbf{8 9 , 4 7 \%}$ dalam kategori tinggi, $\mathbf{0 , 0 0 \%}$ dalam kategori sedang, $\mathbf{0 , 0 0 \%}$ dalam kategori rendah, dan $\mathbf{0 , 0 0 \%}$ dalam kategori sangat rendah. 


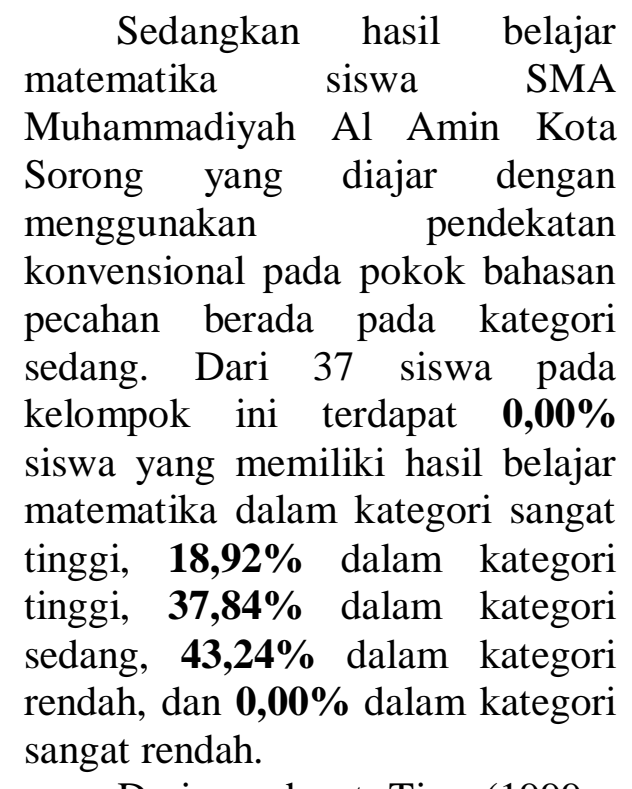

Dari pendapat Tiro (1999 : 200) bahwa keberhasilan proses belajar mengajar salah satunya terlihat dari meningkatnya niali rata-rata. Dari uraian diatas terlihat bahwa hasil belajar matematika pada pokok bahasan pecahan dengan menggunakan pembelajaran terbalik lebih baik dibandingkan hasil belajar siswa pada pokok bahasan pecahan dengan menggunakan pendekatan konvensional.

2. Hasil Analisis Statistik Inferensial Hasil analisis Statistik Inferensial menunjukkan bahwa hasil belajar matematika siswa SMA Muhammadiyah Al Amin Kota Sorong yang diajar dengan menggunakan sistem pembelajaran terbalik lebih baik dari hasil belajar matematika siswa melalui metode konvensional pada pokok bahasan pecahan. Karena rata-rata hasil belajar matematika untuk kelompok eksperimen $(\mathbf{7 5 , 7 9 )}$ lebih tinggi dari rata-rata hasil belajar untuk kelas konvensional $\mathbf{( 5 4 , 8 7 ) . ~}$

Hasil analisis statistik inferensial menunjukkan bahwa hipotesis penelitian diterima. Hal ini dapat dilihat dari uji hipotesis yang menunjukkan bahwa nilai probabilitas $\mathrm{P}=0,000$ lebih kecil dari $\alpha=0,05$. Hasil penelitian telah membuktikan bahwa pendekatan pembelajaran terbalik sangat efektif digunakan dalam pembelajaran matematika.

Meskipun sebagian besar materi pelajaran matematika dapat diberikan melalui pembelajaran terbalik sehingga pembelajaran terbalik dapat memberikan konstribusi yang besar dalam peningkatan pemahaman matematika khususnya pokok bahasan pecahan. Tetapi tidak dapat pula dikatakan bahwa pembelajaran terbalik adalah yang terbaik untuk digunakan melainkan sebagai pertimbangan untuk dijadikan salah satu alternatif pendekatan diantara beberapa pendekatan yang ada dalam pembelajaran matematika.

Perlu diingat bahwa masalah kontekstual tidak selamanya berasal dari aktivitas sehari-hari, melainkan juga berasal dari konteks yang diimajinasikan kedalam pikiran siswa.

\section{Perubahan Aktifitas Siswa}

Upaya guru dalam hal ini peneliti sendiri dalam melihat hasil pendekatan pembelajaran terbalik dalam meningkatkan pemahaman siswa tidak terlepas dari perhatian yang besar 
terhadap perubahan sikap siswa, keaktifan siswa, dan tanggapan siswa terhadap proses pembelajaran yang dialaminya. Hal ini dapat dilihat dari hasil observasi yang dilakukan selama pelaksanaan tindakan.

Hasil observasi menunjukkan bahwa terjadi perubahan yang lebih baik pada setiap siswa dengan memperhatikan indikator yang diamati. Indikator yang diamati yaitu kehadiran siswa, perhatian siswa pada materi dan guru, motivasi siswa, keaktifan siswa dan kedisiplinan siswa dalam mengerjakan tugas/PR.

Pada hasil observasi dapat dilihat bahwa kehadiran siswa selama pelaksanaan tindakan cukup memuaskan. Namun, kehadiran siswa tidak dapat dijadikan indikator tetap karena kehadiran dapat dipengaruhi oleh faktor internal dari dalam diri siswa dan faktor eksternal dari lingkungan siswa, misalnya sakit atau ada urusan lain yang sangat urgen.

Keaktifan siswa baik dalam bertanya kepada temannya atau kepada guru jika menemukan kesulitan, mengungkapkan hasil pemikiran sendiri atau hasil diskusi kelompok didepan teman-temannya yang lain, memberikan komentar atau tanggapan terhadap pendapat temannya maupun keberanian siswa dalam menjawab pertanyaan lisan guru atau menyelesaikan soal latihan dipapan tulis mengalami peningkatan.

Selain memperhatikan keaktifan siswa, guru dalam hal ini peneliti juga memperhatikan siswa yang acuh tak acuh dan mengerjakan pekerjaan lain pada saat proses belajar mengajar berlangsung. Kuantitas siswa yang termasuk dalam hal ini semakin berkurang dari pertemuan pertama sampai terakhir.

Meskipun telah banyak siswa yang aktif masih ada juga siswa yang sangat pasif, tidak mau mengemukakan pendapat atau tidak menjawab pertanyaan lisan guru dan tidak aktif pada saat temannya bekerja, misalnya pada saat penyelesaian masalah, demonstrasi atau bekerja sesuai dengan bahan LKS yang diberikan oleh guru. Hal ini bisa saja terjadi karena disebabkan oleh faktor psikologi siswa tersebut.

Uraian menunjukkan bahwa pendekatan pembelajaran terbalik dapat mengubah siswa menjadi lebih tertarik terhadap matematika bila dibandingkan dengan metode pembelajaran konvensional. Penulis mengatakan hal ini karena diawal pertemuan, pada umunnya siswa mengatakan bahwa matematika itu sulit dan tidak menyenangkan bahkan ada yang merasa takut jika belajar matematika. Setelah pertemuan terakhir pada saat selesai pelaksanaan tes akhir, rata-rata siswa mengatakan tertarik dan senang belajar matematika.

Siswa pada umumnya mengatakan senang dengan alasan cara belajar yang berbeda dari biasanya, adanya pertanyaaan menantang dari guru, pengetahuan baru yang dapat menambah wawasan, dan lebih mengerti karena menyangkut kehidupan sehari-hari. Selain itu ada juga siswa yang mengatakan bahwa keberanian dan rasa percaya dirinya muncul setelah diajar oleh guru dalam hal ini peneliti yang menerapkan 
pembelajaran yang berbeda (menggunakan pembelajaran terbalik).

Dengan adanya perubahan aktifitas siswa mengakibatkan siswa lebih tertarik terhadap matematika. Karena terhadap matematika dengan sendirinya akan berpengaruh pada peningkatan pemahaman siswa terhadap matematika.

\section{KESIMPULAN DAN SARAN}

\section{Simpulan}

Berdasarkan hasil penelitian yang telah diuraikan pada bab IV, maka dapat diambil kesimpulan sebagai berikut:

1. Hasil belajar siswa SMA Muhammadiyah Al Amin Kota Sorong yang diajar dengan menggunakan metode pembelajaran terbalik (reciprocal teaching) mencapai skor rata-rata 75,79 dari skor ideal 100 dengan standar deviasi 5,64.

2. Hasil belajar siswa SMA Muhammadiyah Al Amin Kota Sorong yang diajar melalui metode konvensional mencapai skor rata-rata 54,87 dari skor ideal 100 dengan standar deviasi 10,30.

3. Setelah dilakukan analisis data dari populasi yang berdistribusi normal maka hasil penelitian nilai probabilitas $(\mathrm{P}=0,000)$ lebih kecil dari $(\alpha=0,05)$, sehingga dinyatakan bahwa ada perbedaan antara hasil belajar siswa SMA Muhammadiyah Al
Amin Kota Sorong dalam pembelajaran matematika dengan menggunakan pembelajaran terbalik (reciprocal teaching) dengan siswa yang diajar dengan menggunakan metode konvensional pada pokok bahasan bilangan pecahan.

4. Dengan demikian, dapat disimpulkan bahwa hasil belajar siswa SMA Muhammadiyah Al Amin Kota Sorong yang diajar dengan dengan menggunakan pembelajaran terbalik (reciprocal teaching) dengan siswa yang diajar dengan menggunakan metode konvensional pada pokok bahasan bilangan pecahan.

\section{Saran}

Berdasarkan hasil penelitian serta upaya peningkatan mutu pendidikan dan pengajaran matematika di sekolah SMP, penulis mengemukakan beberapa saran sebagai berikut:

1. Untuk meningkatkan pemahaman siswa dalam belajar matematika maka guru ataupun mahasiswa pendidikan dapat mempelajari dan berusaha mengemukakan pendekatan pembelajaran terbalik (Reciprocal Teaching) yang berorientasi pada matematika pengalaman seharihari dan berupaya membantu siswa menerapkan kembali konsep matematika dalam kehidupan sehari-hari.

2. Kepada peneliti yang akan mengembangkan lebih lanjut 
agar menerapkan pendekatan pembelajaran terbalik dalam ruang lingkup yang lebih luas dan skala yang lebih besar.

3. Kepada pemerintah dalam hal ini yang menangani bidang pendidikan agar memberikan pelatihan dan pendidikan bagi guru-guru yang didalamnya melatih guru sehingga dapat menerapkan pendekatan pembelajaran terbalik (Reciprocal Teaching) disamping menerapkan pendekatan yang lain yang ada dalam pembelajaran matematika.

\section{DAFTAR PUSTAKA}

Depdikbud 2005. Evaluasi dan Penilaian. Proyek Peningkatan Mutu Guru Dirjen DIKDASMEN. Jakarta.

Hamalik, Oemar. 2001. Kurikulum dan Pembelajaran. Bumi Aksara: Jakarta.

Hodoyo. 1990. Strategi Mengajar dan Belajar Matematika. IKIP: Malang.

Mukhtar dan Yamin Martinis, 2003. Metode Pembelajaran yang Berhasil. Edisi ke-3. CV Misaka Galiza: Jakarta.

Muhkal, M. 2002. Strategi Belajar Mengajar Matematika.
Departemen Pendidikan dan Kebudayaan: Makassar

Mukhlis, 2005. Pembelajaran Matematika Realistik Untuk Materi Pokok Perbandingan Negeri I Pallangga. Tesis: Program Studi Pendidikan Matematika Universitas Negeri Surabaya.

Nur, M. dan Wikandari, P.R. 2000. Pengajaran Berpusat Kepada Siswa dan Pendekatan Konstruktivis dalam Pengajaran. Edisi ke-3, Surabaya: Pusat Studi Matematika dan IPA Sekolah. UNESA Surabaya.

Nurbaeti. 2005. Meningkatkan Hasil Belajar Matematika Melalui Pembelajaran Terbalik Pada Siswa Kelas X SMAN I Polut. Skripsi: FKIP Matematika Universitas Muhammadiyah Makassar.

Poerdarminto. 1982. Kamus Bahasa Indonesia. Balai Pustaka: Jakarta.

Sudjana, N. 1989. Cara Belajar Siswa Aktif dalam Proses Belajar Mengajar. Sinar Baru Algesindo: Bandung.

Slameto (1995). Belajar dan FaktorFaktor yang Mempengaruhinya. Rieka Cipta: Jakarta.

Anwar, Z., \& Pandegawati, T. (2018). The Influence Of Tsts Learning 
Model On Mathematic Problem Solving Of Class VII SMP Bukit Zaitun Students'kota Sorong. Jurnal Koulutus, 1(2), 50-70.

Anwar, Z., Layn, M. R., \& Ardyanti, F. (2018). Meningkatkan Minat Dan Hasil Belajar Peserta Didik Dengan Menggunakan Model Pembelajaran Snowball Throwing Melalui Taksonomi
Bloom. Jurnal Noken: Ilmu-Ilmu Sosial, 3(2), 63-76.

Anwar, Z., Layn, M. R., \& Ardyanti, F. (2018). Meningkatkan Minat dan Hasil Belajar Peserta Didik dengan Menggunakan Model Pembelajaran Snowball Throwing Melalui Taksonomi Bloom. Jurnal Noken: IlmuIlmu Sosial, 3(2), 63-76. 